\title{
Retention Factors and Their Relative Significance in Ceramic Manufacturing Industries in India
}

\author{
S. Umamaheswari ${ }^{1} \&$ Jayasree Krishnan ${ }^{2}$ \\ ${ }^{1}$ Faculty of Business Administration, Sathyabama University, Chennai, India \\ ${ }^{2}$ Department of Management Studies, St. Joseph's College of Engineering, Chennai, India \\ Correspondence: S. Umamaheswari, Faculty of Business Administration, Sathyabama University, Chennai, India. \\ E-mail: umaaishwarya99@gmail.com
}

\author{
Received: December 31, 2014 Accepted: March 4, 2015 Online Published: May 16, 2015 \\ doi:10.5539/ass.v11n13p260 URL: http://dx.doi.org/10.5539/ass.v11n13p260
}

\begin{abstract}
Due to the tough competition prevailing in the manufacturing industries, retention of employees has become a challenge for the organizations. Surveys predicted that there is a strong growth in ceramic sector. Therefore special attention is given in this paper to analyze the factors influencing employees' continuation in ceramic manufacturing industries. Work life balance \& policies, organization commitment, supervisor support and training \& development were the four non-monetary factors considered for analysis. This study explored the facts over employees of ceramic manufacturing industries in India. Statistical tools were utilized to analyze the influence of variables. The analysis revealed that all the four factors were correlated to employee retention. The findings also concluded that work life balance \& policies, organization commitment and supervisor support exerted significant influence with employee retention. It is also found that supervisor support exerted more influence that other two factors. Suggestions and limitations of the study were also incorporated.
\end{abstract}

Keywords: employee retention, work life balance \& policies, organization commitment, supervisor support, training \& development, ceramic manufacturing industries

\section{Introduction}

Employees are considered as the heart and soul of an organization. Most of the manufacturing industries mainly depend on their workforce for their production though some major firms utilize latest technology of automation. Even for them, work force is essential to operate and maintain their machineries. Further possessing of critical employees differentiates them from their competitors. But in reality industrialization provided wider scope for able employees to mobilize towards better opportunities and pulling of capable employees by the competitors can also occur creating a deficit in the required work force. The benefits of retaining critical employee include the ability of the company to achieve strategic business objectives and to gain a competitive advantage over its current and potential competitors (Ramlall, 2003).

Knowledgeable workers play a vital role in the business activities of the organizations. One of the characteristics of knowledge workers is their high level of mobility. The cost of labour turnover of the key resources is high in both financial and non-financial terms. There is, thus a need to understand what the factors are that underpin the retention of cognitions of knowledge workers (Sutherland \& Jordaan, 2004). The researchers Sutherland \& Jordaan (2004) concluded from their study that the need of high individualism, the need for challenge and the career management desires of this new breed of workers who are unique and increasingly important contributors to the knowledge based economy is to be considered in the formation of retention strategy. Organizations should have a proactive retention strategy so as to satisfy the employees who differ by roles, needs and their motivation to the maximum extent (Ragupathi, 2013).Hence organizations, particularly manufacturing industries are giving their utmost priority in retaining their employees apart from giving importance to acquire raw materials for their products.

\subsection{Significance of the Study}

The studies by Hay group(2013) observed that higher attrition rate of over $26 \%$ exists in India and survey on manufacturing industries predicted a strong growth of over $10 \%$ in ceramic sector in April-June 2014-2015(FICCI,2014), which increased the necessity of more employees. The general strategy of "pay more 
and retain" results in escalation of production cost, which diminished the chances in capturing domestic and international market. Thus organizations are looking for non- monetary factors effecting retention. Moreover pay is clearly not the most important issue in employee turnover however, a certain level of pay is needed to recruit and retain (Boxall, Macky, \& Rasmussen, 2003). Researchers Yiu \& Saner (2014) outlined in their article that turnover cannot be smoothened by salary increase and by costly extrinsic incentives alone. Hence non-financial factors also plays considerable role in the retention of employees. Further, motivation for job change is a multi-dimensional and no one factor will explain it (Boxall et al., 2003). There is no globally accepted formula to prevent turnover and it is needful to formulate suitable retention strategies to compete in the global market giving importance to the critical factors influencing retention of employees (Nwokocha \& Iheriohanma, 2012). This necessitated the research and main factors focused in this article were work life balance \& policies, organization commitment, supervisor support and training \&development. As ceramic sector is less attended one, this article explores the influence of above non-financial factors and their relative significance over employee's working in ceramic manufacturing industries in India.

\subsection{Literature Review}

\subsubsection{Work Life Balance \& Policies and Retention}

Work life balance involves balancing career demands with personal and family needs (Gupta, 2010). Work life policy is the organization's methods adopted for satisfying the needs of employees to balance work and their life. Policy on work life balance varies from organization to organization. Various combinations of options were offered to the employees. Some of the options include job sharing, part time working, staged working hours, occasionally working at home, and leaves etc. (Sanghi, 2012). Work life balance is increasingly an important factor for employee retention and people are leaving their jobs, to acquire better work life balance (Boxall et al., 2003). Supportive work culture characterized by work time and work life flexibilities contributes to increased work life balance and make employee more proactive. This kind of corporate culture has a strong role to play between work life balance \& practices and human resource issues like retention and turn over (Kar \& Misra, 2013). Work life balance have an impact on employee retention and work life policies plays a role of obtaining a balance between work and life. It encourages employee's decision to remain with the organization (Shoaib, Noor, Tirmizi, \& Bashir, 2009). According to recent research published in training \& development $69 \%$ absences are not due to illness but occur because employees decide to attend their personal needs. This may cost an employer over $\$ 600$ per absence. The financial health of a company is linked to personal health of the human capitals. (Work/Life Initiatives Impact Employee Retention, 2003). Flexible working practices helps staff to strike a balance between paid work and personal life, can lead to improved recruitment and retention, reduction of absenteeism and an improved staff commitment and productivity (Manfredi \& Holliday, 2004). Job retention is positively associated with the employer's promotion of work life balance (Smith, 2005).

The Mccrindle study of 3000 Australians showed that work life balance is the number one factor of job attraction and retention (even above salary) (Pleffer, 2007). One of the main reasons for employee's stay in their company is flexible work schedule (Ramlall, 2003). Both perceived flexibility and supportive work life balance \& policies significantly increase the likelihood of expected retention (Richman, 2006). Work life programme have the potential to significantly improve employee morale, reduce absenteeism, and retain organizational knowledge, particularly during difficult economic times. Also work life programmed offer a win- win situation for employers and employees (Lockwood, 2003). An exploratory study on the views of male workers by the researchers Hughes \& Bozionelos (2007) indicated the existence of clear correlation between problems with work life balance and withdrawal behaviors including turnover and non-genuine sick absence. According to new research from Hay Group (April 16, 2013) more than one in four employees $(27 \%)$ at organization that are not perceived to support work life balance plan to leave their companies within next two years. The authors Cegarra-LeivaSánchez-Vidal \& Cegarra-Navarro (2012) while analyzing the effect of work life balance over managers found that informal support for work life balance is expressed through the existence of positive and supportive organizational values for work life balance, plays a major role in enhancing organizational out comes such as job satisfaction among mangers and their retention in small and medium enterprises. The above literature review reveals that work life balance \&policies is an important factor for retention.

\subsubsection{Organization Commitment \& Retention}

Organization commitment is the extent to which an employee feels a sense of allegiance and loyalty to /his/her employer. Organization commitment is the emotional reaction of employees towards an organization and its policies. Organization commitment is getting attention due to its ability to produce desirable outcomes for the people of the organization (Haldar \& Pareek, 2009). Organization commitment was found to be the most 
influential factor in affecting employee's staying intention (Othman \& Ghazali, 2014). Strong organization commitment derives and shapes the organization culture that promotes a sense of belonging and ownership among employees essential for being satisfied, productive and loyal employees, hence reduces turnover intention (Hussain \& Asif, 2012). A strong inverse relationship is also confirmed by the research of (Jehanzeb, Rasheed, \& Rasheed, 2013) between organization commitment and turnover intention. Affective commitment of employees is negatively and significantly related to employees' turnover intention (Joarder, Sharif, \& Ahmmed, 2011).

The researcher Arthur (1994) found that employees with more commitment towards their organization perform better and also noticed increased efficiency and production quality in their job. Hence organization prefers philosophy of commitment to minimize their employees' turnover. Work values are related to various facts of job satisfaction, which in turn influence commitment to the organization (Froese \& Xiao, 2012). Intention to quit is largely influenced by lack of commitment to the organization(Firth, Mellor, Moore \& Loquet,2004).Research conducted by Parasuraman (1982) found that organization commitment of employees was one of the strongest predictors of turnover intentions. The research by Salleh Nair \& Harun (2012) provided empirical support that organization commitment was significantly and negatively related to turnover intention. According to Steers, (1977) who carried out the study among 382 hospital employees and 119 scientists and engineers found that for both samples, personal characteristics, job characteristics, and work experiences influenced commitment. Moreover, commitment was found to be strongly related to intent and desire to stay. Also organizational commitment played a very important role in affecting a person's decision to stay (Igbaria, Meredith, \& Smith, 1994). The above findings give evidence that organization commitment is an important factor for employee retention.

\subsubsection{Supervisor Support and Retention}

Organizations feel that the supervisors are the sources of general assistance in the efforts to retain their critical employees (Ramlall, 2003). The quality of relationship between supervisor and employees is an important factor in retaining individuals (Boxall et al., 1993). Supervisor support is a major contributor for employee retention amongst all other determinants (Shoaib et al., 2009). The research by Gentry, Kuhnert, Mondore, \& Page (2007) on blue-collar part time workers in U.S.A revealed that "perceived supervisor support levels were related to retention rates" and this clearly shows that supervisor support is an important predictor of retention. Employees who perceived high support expressed stronger feelings of affiliation and loyalty to the organization as perceived support related to supervisor's evaluations; the relationship with supervisor plays an important role in employee's decision of stay in the organization (Eisenberger, Fasolo, \& Davis-LaMastro, 1990). Supervisory relationships were rated as an important factor in the decision of continuation with the company and also perceived poor treatment by a supervisor leads to turnover (Borstorff \& Marker, 2007). Supervisor role is becoming very crucial for organization. Supervisors are influenced in directing a clear career vision to employees thus enhancing dependence on organizational career management. The encouragement of a more interactive and coaching approach via supervisors would facilitate the development of trust and confidence from employees and they will be more willing to strive for organization goal in return (Tan, 2008).

Employees who believed that the supervisor valued their contribution and cared about their well-being showed increased perceived organization support, which in turn was related to decreased turnover. Also employees with low perceived organization support may believe that their prospective success in the organization is greatly limited. Thus a reduction of perceived organization support, resulting from perceived supervisor support or other resources may increase employee's likely hood of quitting the organization. (Eisenberger, Stinglhamber, Vandenberghe, Sucharski, \& Rhoades, 2002). If bosses are supportive, encouraging and let employees to learn from mistakes, more the employees feel sense of pride in their jobs. Supervisors or the managers of the organization play a vital role in employee retention (Fatima, 2011). The researchers Ng'eno Williter Chepkemoi Rop (2014) predicted that employee's work appreciation, freedom to make job-related decision, mentorship and career development granted by the supervisor had a high and positive significance with supervisor's influence on employees to continue in the firm and hence supervisor-employee relationship is an important attribute that significantly affects retention of millennial employees at their work places. There exists direct relationship between supervisor support and turnover decision of faculty member of private universities of Bangladesh (Joarder et al., 2011). Supervisor support plays a crucial role in increasing the enthusiasm among employees which leads to job satisfaction and employee retention (Hassan, Razi, Qamar, Jaffir, \& Suhail, 2013). Supportive and competent supervisor positively associated with job retention (Smith, 2005). The above mentioned literature survey revealed that supervisor support is an important determinant of employee's retention. 


\subsubsection{Training \& Development and Retention}

The overall aim of a training programme is to fill the gap between existing and desired pool of knowledge, skills and aptitudes. The objectives of training express the gap between the present and desired performance levels. (Gupta, 2010). In order to enhance employees' performance to meet global challenge managerial learning frame work is required (Garg \& Rastogi, 2006). The more knowledge the employee acquire the more will be their performance .The necessity of increased skills and efficiencies of employees had been felt by organization and they are investing on training programmes. The investment on work practices are justified and encouraged as they are associated with greater productivity and corporate financial performance and lower employee turnover. (Huselid, 1995). The study by the researcher Ragupathi, (2013) identified that training is the fundamental consideration for the employee's retention decision. Training and career development has significant positive association with intention to stay (Chew \& Chan, 2008). Training, its types and direction is a key variable that lead to job satisfaction and employee retention (Hassan et al., 2013). The finding of the study by Ashar, Ghafoor, Munir, \& Hafeez (2013). Support the notion that affective commitment of employees is highly effected by perception of training and also depict inverse relationship between affective types of commitment and turn over intentions. Training \& development is contributing strongly in developing employees' intention to stay with the organization. (Hussain \& Rehman, 2013).

According to Tangthong, Trimetsoontorn, \& Rojniruntikul (2014) though training \& development does not have a complete role in determining employee retention, it exerts direct and indirect effects when it is combined with compensation and reward benefits. Training can be an important tool for retaining employees, but it can see that the impact of training on compensation of an employee can be very crucial for retention (Anis, Ijaz-Ur-Rehman, \& Safwan, 2011). The researchers Hong, Hao, Kumar, Ramedran, \& Kadiresan (2012) while analyzing the retention effects of variables, found that training \& development provided to employees had significant influence. The study of Huselid (1995) provided broad evidence to the fact that use of high performance work practices will be reflected better firm performance. Also work practices such as providing training and employment security by the company are important factors associated with employee turnover. The literature survey revealed that training is one of the important determinants for job retention.

\subsubsection{Objectives of the Study}

1) To examines the influence of work life balance \& policies, organization commitment, supervisor support, and training \& development (independent variables) on employee retention (dependent variable).

2) To predict their relative significance.

\subsubsection{Hypothesis}

As discussed above the following hypothesis are proposed in the present study.

$\mathrm{H}_{1}$-There is an association \& significant relationship between work life balance \& policies and employee retention.

$\mathrm{H}_{2}$-There is an association \& significant relationship between organization commitment and employee retention.

$\mathrm{H}_{3}$-There is an association and significant relationship between supervisor support and employee retention.

$\mathrm{H}_{4}$ - There is an association and significant relationship between training \& development and employee retention.

\section{Method}

\subsection{Sample and Procedure}

Respondents in the study were staff of ceramic manufacturing factories in India. Out of 550 self-administrated questionnaires distributed to the staff of the above factories, 416 usable questionnaires were used in the statistical analysis representing a response rate of $75 \%$ (approx.) from the sample. The selection of the respondent is based on the simple random sampling.

\subsection{Profile of the Respondents}

Respondents of the study comprises of 25-45 age group (81\%) and 57\% belongs to 5-15 years of service. As regards to educational qualification approximately $73 \%$ of them possess post graduate and professional qualification. Majority of the respondents work in production department and they hold middle level managers post.

\subsection{Measurement}

The independent variables of the study were work life balance \&policies, organization commitment, supervisor 
support, training \& development. Totally 35 questions exists in the questionnaire. There were five questions for work life balance \& policies and eight questions for organization commitment .Another five questions were floated to measure supervisor support and seven questions for training \& development. Dependent variable is employee retention with 10 questions. Respondents were asked to respond the questionnaire on a Likert- scale range from 1- 5 with $1=$ strongly disagree and $5=$ strongly agree. Statistical package for the social sciences (SPSS) has been employed for analyzing the collected data. The researcher developed the questionnaire based on self-administration and adoption from previous papers (Dockel, 2003; Chew, 2004; Wang, 2012; Sophia, 2007; Mowday, Steers, \& Porter, 1979; Atkinson, 2011; Olafsdottir, 2008).

\section{Results \& Discussion}

Table 1. Mean, standard deviation and Cronbach's alpha

\begin{tabular}{lllll}
\hline Variables & Mean & Standard Deviation & No of item & Cronbach's alpha \\
\hline Work life balance \& policies & 21.46 & 2.09 & 5 & 0.766 \\
Organization commitment & 34.26 & 3.32 & 8 & 0.829 \\
Supervisor support & 21.29 & 2.21 & 5 & 0.785 \\
Training \& development & 25.11 & 2.51 & 7 & 0.818 \\
Employee retention & 41.50 & 4.482 & 10 & 0.902 \\
\hline
\end{tabular}

Table 1 shows the mean, standard deviation and Cronbach's alpha for each variable. It depicts the reliability coefficient of variables which ranges from 0.766 to 0.902 which concurs with minimum acceptable level of 0.70 (Nunnaly, 1994) and also explains the mean value which ranges from 21.29 to 41.50 .

Table 2. Correlation coefficient between and dependent and independent variables

\begin{tabular}{|c|c|c|c|c|c|c|}
\hline Variables & $\begin{array}{l}\text { Work } \\
\text { balance } \\
\text { policies }\end{array}$ & $\begin{array}{r}\text { life } \\
\&\end{array}$ & $\begin{array}{l}\text { Organization } \\
\text { commitment }\end{array}$ & $\begin{array}{l}\text { Supervisor } \\
\text { support }\end{array}$ & $\begin{array}{l}\text { Training and } \\
\text { development }\end{array}$ & $\begin{array}{l}\text { Employee } \\
\text { Retention }\end{array}$ \\
\hline $\begin{array}{l}\text { Work life balance } \\
\text { \& policies }\end{array}$ & 1 & & & & & \\
\hline $\begin{array}{l}\text { Organization } \\
\text { commitment }\end{array}$ & $0.687^{* *}$ & & 1 & & & \\
\hline Supervisor support & $0.528^{* *}$ & & $0.654^{* *}$ & 1 & & \\
\hline $\begin{array}{l}\text { Training } \\
\text { development }\end{array}$ & $0.566^{* *}$ & & $0.603^{* *}$ & $0.604^{* *}$ & 1 & \\
\hline $\begin{array}{l}\text { Employee } \\
\text { Retention }\end{array}$ & $0.602 * *$ & & $0.634^{* *}$ & $0.700^{* *}$ & $0.539 * *$ & 1 \\
\hline
\end{tabular}

** Correlation is significant at the $1 \%$ level ( 2 tailed)

Table 3. Model summary and Anova for regression analysis

\begin{tabular}{ll}
\hline $\begin{array}{l}\text { Dependent } \\
\text { Variable }\end{array}$ & Employee retention \\
\hline Predictors & $\begin{array}{l}\text { Work life balance \& policies, Organization commitment, Supervisors support, Training \& } \\
\text { development }\end{array}$ \\
Multiple R value & 0.759 \\
R square value & 0.577 \\
F value & 140.065 \\
P value & 0.000 \\
\hline
\end{tabular}

Table 2 shows the coefficient of correlation between dependent and independent variables. It is observed that all the variables are positively correlated with each other. The correlation ranges from $54 \%$ to $70 \%$.Supervisor support is highly correlated(70\%) with employee retention and other three variables lies between $54 \%$ to $63 \%$ proving the acceptance of all the hypothesis $\mathrm{H}_{1}, \mathrm{H}_{2}, \mathrm{H}_{3}, \mathrm{H}_{4}$ and all of them falls under significant at $1 \%$ level. 
Table 4. Variables in the multiple regression analysis

\begin{tabular}{lllll}
\hline \multirow{2}{*}{ Variables } & \multicolumn{2}{l}{ Unstandardized coefficients } & \multirow{2}{*}{ Sig } \\
& $\beta$ & Std. error & & \\
\hline constants & 3.065 & 1.705 & 1.799 & 0.073 \\
Work life balance \& policies & 0.505 & 0.098 & 5.152 & $0.000^{* *}$ \\
Organization commitment & 0.206 & 0.069 & 2.986 & 0.003 \\
Supervisor support & 0.895 & 0.090 & 9.95 & $0.000^{* *}$ \\
Training \& development & 0.069 & 0.075 & 0.919 & 0.359 \\
\hline
\end{tabular}

Dependent variable: employee retention $* \mathrm{p}<0.05 ; * \mathrm{*}<<0.01$

Dependent variable $=3.065+0.505+0.206+0.895+0.069$.

Table 3 and 4 shows that the multiple correlation coefficients is 0.759 .It measures the degree of relationship between the actual values and predicted values of employee retention. Because predicted values are obtained as a linear combination of independent variables, the coefficient value of 0.759 indicates that the relationship between the dependent and four independent variables are quite strong and positive. The co-efficient of determination (R square value) measures the goodness-of fit of the estimated sample regression plan (SRP) in terms of the proportion of the variation in the dependent variables explained by the fitted sample regression equation. Thus the value of $\mathrm{R}$ square is 0.577 . It means that $57.7 \%$ of the variation in employee retention is explained by estimated SRP that uses the work life balance \& policies, organization commitment, supervisor support, training \& development as the independent variable and $\mathrm{R}$ square value is significant at $1 \%$ level.

The multiple regression equation is employee retention $=3.065+0.505$ (work life balance $\&$ policies) +0.206 (organization commitment) +0.895 (supervisor support) +0.069 (training \& development). Here, the coefficient of 0.505 represents the partial effect of work life balance \& policies on employee retention holding other three variables as constants. Estimated positive sign implies that such effect is positive that employee retention would increase by 0.505 for every unit increase in work life balance \& policies and this co-efficient value is significant at $1 \%$ level. The coefficient of organization commitment 0.206 which represents the partial effect of organization commitment on employee retention holding other variables as constants. The estimated positive sign implies that such effect is positive that employee retention would increase by 0.206 for every unit increase in organization commitment this coefficient is significant at $1 \%$ level. Similarly coefficient of supervisor support is 0.895 . It represents the partial effect of supervisor support on employee retention holding other three variables as constants. The estimated positive sign implies that such effect is positive that employee retention would increase by 0.895 for every unit increase in supervisor support and coefficient value is significant at $1 \%$ level. Likewise the coefficient value of training \& development is 0.069 .It represents the partial effect of training \& development on employee retention. The estimated positive sign implies such effect is positive that employee retention would increase by 0.069 for every unit increase in training \& development and the coefficient value is not significant at $5 \%$ level.

The results derived from correlation matrix revealed that work life balance \& policies, organization commitment supervisor support and training \& development were positively related to employee retention. The regression analysis explored that the three independent variables namely work life balance \& policies, organization commitment and supervisor support had significant influence on employee retention. In other words, out of the four variables, work life balance \& policies, organization commitment and supervisor support were more predominant factors for the employee retention. The result derived from the data collected predicted that supervisor support acts as a predominant factor having significance over employee retention which coincides the previous research studies (Eisenberger et al., 1990; Boxall et al., 2003; Umamaheswari \& Krishnan, 2014). This may be due to fact that organization are for their better governance, decentralized and supervisors are considered as "mini organizations" and their supportive nature enhances the employee's confidence and attachment towards supervisors results in dedicated work. This full fills the organization target, consequently employees were rewarded. On the other side, if the relationship in rough and turbulent, the employee will have fatigue, displeasure and may try for change. The next factor which gives considerable influence is work life balance \& policies is coincided with the previous research (Boxall et al., 2003; Richman, 2003). This may due to the fact that employees-friendly policies fulfill their personnel need and they will be carrying out their job enthusiastically and without any diversion. Due to this dedication, organization targets can be achieved earlier and can result in rewards and perks. On the other hand, conflict in work and family life leads to switching over. 
Also as per analysis organization commitment emerged as a significant factor employees retention and this is consistent with the pervious study (Steers, 1977; Igbaria et al., 1994). And lack of organization commitment influence intention to quit and this coincided with previous study (Firth et al., 2004).

\section{Conclusions}

The study revealed that employee's continuation in firm is significantly related to the relationship that exists between supervisors and employees. Also the results gives evidence that work life balance \& policeis and organization commitment also have significant relationship with employee retention in ceramic manufacturing industries in India. Based on this study it is suggested that organizations, while preparing retention strategies should give special emphasis for the cordial relationship between supervisors and employees. Employee friendly policies and factors for improving emotional attachment towards the organization also should be taken into consideration while the retention strategies are prepared.

Like other studies, this study also has its own limitations. The research had been carried out in a specific country which limits generalization. Further, existence of junior staff among respondents and the assumption that they also know the organization well and fully is another limitation. In future the research can be tried with different variables and in different industries for getting more detailed reports.

\section{References}

Anis, A., Ijaz-Ur-Rehman, A. N., \& Safwan, N. (2011). Employee retention relationship to training and development: A compensation perspective. African Journal of Business Management, 5(7), 2679-2685.

Arthur, J. B. (1994). Effects of human resource systems on manufacturing performance and turnover. Academy of Management Journal, 37(3), 670-687. http://dx.doi.org/10.2307/256705

Ashar, M., Ghafoor, M., Munir, E., \& Hafeez, S. (2013). The impact of perceptions of training on employee commitment and turnover intention: Evidence from Pakistan. International Journal of Human Resource Studies, 3(1), 74. http://dx.doi.org/10.5296/ijhrs.v3i1.2924

Atkinson, C. M. (2011). Examining Differences in Work-life Balance, Job Satisfaction, Organizational Commitment, and Learning Goal Orientation in Baby Boomers and Generation Xers. Doctoral dissertation, San Diego State University.

Borstorff, P. C., \& Marker, M. B. (2007). Turnover Drivers and Retention Factors Affecting Hourly Workers: What is Important. Management Review: An International Journal, 2(1), 14-27.

Boxall, P., Macky, K., \& Rasmussen, E. (2003). Labour turnover and retention in New Zealand: The causes and consequences of leaving and staying with employers. Asia Pacific Journal of Human Resources, 41(2), 196-214. http://dx.doi.org/10.1177/10384111030412006

Cegarra-Leiva, D., Sánchez-Vidal, M. E., \& Cegarra-Navarro, J. G. (2012). Work life balance and the retention of managers in Spanish SMEs. The International Journal of Human Resource Management, 23(1), 91-108. http://dx.doi.org/10.1080/09585192.2011.610955

Chew, J. C. L. (2004). The influence of human resource management practices on the retention of core employees of Australian organizations: An empirical study. Doctoral dissertation, Murdoch University.

Chew, J., \& Chan, C. C. (2008). Human resource practices, organizational commitment and intention to stay. International Journal of Manpower, 29(6), 503-522. http://dx.doi.org/10.1108/01437720810904194

Dockel, A. (2003). The effect of retention factors on organizational commitment, an investigation of high technology employees. Masters dissertation, University of Pretoria. Retrieved from http://Pretoria.upetd.up.ac.za/thesis/available/etd-08282003-103618/.../dissertation.pdf

Eisenberger, R., Fasolo, P., \& Davis-LaMastro, V. (1990). Perceived organizational support and employee diligence, commitment, and innovation. Journal of applied psychology, 75(1), 51. http://dx.doi.org/10.1037/ 0021-9010.75.1.51

Eisenberger, R., Stinglhamber, F., Vandenberghe, C., Sucharski, I. L., \& Rhoades, L. (2002). Perceived supervisor support: contributions to perceived organizational support and employee retention. Journal of applied psychology, 87(3), 565. http://dx.doi.org/10.1037/0021-9010.87.3.565

Fatima, H. (2011). Does employee retention affect organizational competence? Industrial Engineering Letters, $1(1), 24-39$.

FICCI. (2014). Quarterly survey on Indian manufacturing sector May 2014, Federation of Indian chambers of commerce and industry manufacturing division. Retrieved from http://www.FICCI.com./manufacturingsurvey-report-2014.pdf 
Firth, L., Mellor, D. J., Moore, K. A., \& Loquet, C. (2004). How can managers reduce employee intention to quit? Journal of managerial psychology, 19(2), 170-187. http://dx.doi.org/10.1108/02683940410526127

Froese, F. J., \& Xiao, S. (2012). Work values, job satisfaction and organizational commitment in China. The International Journal of Human Resource Management, 23(10), 2144-2162. http://dx.doi.org/10.1080/0 9585192.2011 .610342

Garg, P., \& Rastogi, R. (2006). New model of job design: motivating employees' performance. Journal of Management Development, 25(6), 572-587. http://dx.doi.org/10.1108/02621710610670137

Gentry, W. A., Kuhnert, K. W., Mondore, S. P., \& Page, E. E. (2007). The influence of supervisory-support climate and unemployment rate on part-time employee retention: A multilevel analysis. Journal of Management Development, 26(10), 1005-1022. http://dx.doi.org/10.1108/02621710710833432

Gupta, C. B. (2010). Human Resource Management. Sultan Chand \& Sons, New Delhi.

Haldar, U. K., \& Pareek, U. (2009). Human Resource Development. Oxford University Press.

Hassan, W., Razi, A., Qamar, R., Jaffir, R., \& Suhail, S. (2013). The Effect of Training on Employee Retention. GJMBR-A: Administration and Management, 13(6).

Hay Group. (2013). 1 in 4 Indian employees set to switch jobs as growth picks up. Retrieved from http://www.haygroup.com/in/press/details.aspx?id=37383

Hong, E. N. C., Hao, L. Z., Kumar, R., Ramedran, C., \& Kadiresan, V. (2012). An effectiveness of human resource management practices on employee retention in institute of higher learning: A regression analysis. International Journal of Business Research and Management, 3(2), 60-79.

Hughes, J., \& Bozionelos, N. (2007). Work-life balance as source of job dissatisfaction and withdrawal attitudes: An exploratory study on the views of male workers. Personnel Review, 36(1), 145-154. http://dx.doi.org/10. $1108 / 00483480710716768$

Huselid, M. A. (1995). The impact of human resource management practices on turnover, productivity, and corporate financial performance. Academy of management journal, 38(3), 635-672. http://dx.doi.org/10. $2307 / 256741$

Hussain, T., \& Asif, S. (2012). Is employees' turnover intention driven by organizational commitment and perceived organizational support. Journal of Quality and Technology Management, 8(2), 1-10.

Hussain, T., \& Rehman, S. S. (2013). Do Human Resource Management Practices Inspire Employees' Retention? Research Journal of Applied Sciences, Engineering and Technology, 6(19), 3625-3633.

Igbaria, M., Meredith, G., \& Smith, D. C. (1994). Predictor of intention of is professionals to stay with the organization in South Africa. Information \& Management, 26(5), 245-256. http://dx.doi.org/10.1016/03787206(94)90063-9

Jehanzeb, K., Rasheed, A., \& Rasheed, M. F. (2013). Organizational Commitment and Turnover Intentions: Impact of Employee's Training in Private Sector of Saudi Arabia. International Journal of Business and Management, 8(8), 79. http://dx.doi.org/10.5539/ijbm.v8n8p79

Joarder, M. H., Sharif, M. Y., \& Ahmmed, K. (2011). Mediating role of affective commitment in HRM practices and turnover intention relationship: A study in a developing context. Business and Economics Research Journal, 2(4), 135-158.

Kar, S., \& Misra, K. C. (2013). Nexus between Work Life Balance Practices and Employee Retention-The Mediating Effect of a Supportive Culture. Asian Social Science, 9(11), 63. http://dx.doi.org/10.5539/ass. v9n11P63

Lockwood, N. R. (2003). Work/Life Balance. Challenges and Solutions, SHRM Research, USA.

Manfredi, S., \& Holliday, M. (2004). Work-life balance: An audit of staff experience at Oxford Brookes University. Oxford Brookes University. Retrieved from https://www.brookes.ac.uk/services/hr/eod/wlb/ wlb_report.pdf

Mowday, R. T., Steers, R. M., \& Porter, L. W. (1979). The measurement of organizational commitment. Journal of vocational behavior, 14(2), 224-247. http://dx.doi.org/10.1016/0001-8791(79)90072-1

Nasyira, M. N., Othman, M., \& Ghazali, H. (2014). Predictors of intention to stay for employees of casual dining restaurant in Klang Valley area. International Food Research Journal, 21(3).

Njoroge, S. W. (2007). A Survey of factors that influence employee retention in manufacturing firms in Nairobi. Masters Dissertation, University of Nairobi. 
Nunnally, J. C., \& Bernstein, I. H. (1994). Psychometric Theory, (3). McGraw-Hill. New York.

Nwokocha, I., \& Iheriohanma, E. B. J. (2012). Emerging trends in employee retention strategies in a globalizing economy: Nigeria in focus. Asian Social Science, 8(10), 198. http://dx.doi.org/10.5539/ass.v8n10p198

Olafsdottir, S. (2008). The role of organizational culture in employees' work-life balance as an aspect of health. Master's thesis, Nordic School of Public Health.

Parasuraman, S. (1982). Predicting turnover intentions and turnover behavior: A multivariate analysis. Journal of Vocational Behavior, 21(1), 111-121. http://dx.doi.org/10.1016/0001-8791(82)90056-2

Pleffer, A. (2007). Work-life Balance: The Number 1 Retention Factor. Retrieved from http://www.community west.com.au/component/.../90-work-life-balance

Ragupathi, D. (2013). The Employee Retention Practices of MNCS in Hyderabad. Research Journal of Management Sciences.

Ramlall, S. (2003). Organizational Application Managing Employee Retention as a Strategy for Increasing Organizational Competitiveness. Applied HRM Research, 8(2), 63-72.

Richman, A. (2006). Everyone wants an engaged workforce how can you create it? Work span, 49(1), 36-39.

Rop, N. W. C., Amuhaya, M. I., Kanali, H., \& Chepkilot, R. (2014). The Influence of Supervisor-Employee relationship on retention of millennial employees in private hospitals in Bomet and Kericho countries, Kenya. International Journal of Advanced Research (2014), 2(3), 441-447.

Salleh, R., Nair, M. S., \& Harun, H. (2012). Job Satisfaction, Organizational Commitment, and Turnover Intention: A Case Study on Employees of Retail Company in Malaysia. World Academy of Science, Engineering and Technology, 72, 316-323.

Seema, S. (2012). Human resource management. Macmillan Publishers India.

Shoaib, M., Noor, A., Tirmizi, S. R., \& Bashir, S. (2009, November). Determinants of employee retention in telecom sector of Pakistan. In 2nd COMSATS International Business Research Conference, Lahore, Pakistan.

Smith, B. D. (2005). Job retention in child welfare: Effects of perceived organizational support, supervisor support, and intrinsic job value. Children and Youth Services Review, 27(2), 153-169. http://dx.doi.org/10. 1016/j.childyouth.2004.08.013

Steers, R. M. (1977). Antecedents and outcomes of organizational commitment. Administrative science quarterly, 46-56. http://dx.doi.org/10.2307/2391745

Sutherland, M., \& Jordaan, W. (2004). Factors affecting the retention of knowledge workers. SA Journal of Human Resource Management, 2(2), 55. http://dx.doi.org/10.4102/sajhrm.v2i2.39

Tan, F. M. (2008). Organizational Support As the Mediator of Career-Related Hrm Practices and Affective Commitment: Evidence from Knowledge Workers in Malaysia. Research \& Practice in Human Resource Management, 16(2).

Tangthong, S., Trimetsoontorn, J., \& Rojniruntikul, N. (2014). HRM Practices and Employee Retention in Thailand-A Literature Review. International Journal of Trade, Economics \& Finance, 5(2). http://dx.doi. org/10.7763/IJTEF.2014.V5.362

Umamaheswari S., \& Krishnan, J. (2014). Determinants of Employee Retention-Factors and Analysis in Manufacturing Industries in India. International Business Management, 8, 214-221.

Wang, Y. H. (2012). Recruitment and Retention of Knowledge Workers in Taiwan's High Technology Industry. Doctoral dissertation, Section of Cardiff Business School, Cardiff University.

Work/Life Initiatives Impact Employee Retention. (2003). Retrieved from The Retentioneer (Vol. 3). Retrieved from http://retensa.com/knowledgebase

Yiu, L., \& Saner, R. (2014). Talent Attrition and Retention: Strategic Challenges for Indian Industries in the Next Decade. Elite Research Journal of Accounting and Business Management, 2(1), 1-9.

\section{Copyrights}

Copyright for this article is retained by the author(s), with first publication rights granted to the journal.

This is an open-access article distributed under the terms and conditions of the Creative Commons Attribution license (http://creativecommons.org/licenses/by/3.0/). 